\title{
The Relationship between Labour NGOs and Chinese Workers in an Authoritarian Regime
}

\author{
Anita Chan, Australian National University, Australia
}

\begin{abstract}
Labour NGOs have played a role, especially in southern China, in raising Chinese workers' consciousness. This paper takes a historical perspective and argues that the relationship between labour NGOs and workers has changed in the past three decades, from one of workers' dependency on Chinese labour NGOs and these NGOs' dependency, in turn, on foreign NGOs in an asymmetrical relationship, to one more of partnership. More recently, some groups of workers have become cognisant of a divergence of interests between themselves and NGO advisors. The evolving relationship is analysed against the backdrop of an authoritarian political regime that necessitates all the actors to strategise in complex ways. A coordinated wave of strikes and other collective actions at Chinese Walmart stores in 2016 provides a case study.
\end{abstract}

\section{KEY WORDS}

China; workers; Chinese labour NGOs; Hong Kong labour NGOs; Walmart

It has been some thirty years since China opened up to global capitalism and domestic capitalism. Like so many countries in the Global South, China has served as a supplier of cheap labour for the global production chain - and on a grand scale. Much has been documented about labour exploitation in China's export industrial sector, where the large majority of the workers are migrants from poor rural parts of China labouring in the richer coastal regions. While the size of this pool of labour has continued to expand, reaching more than 150 million, China's official trade union federation, the All-China Federation of Trade Unions (ACFTU), China's only trade union, has barely changed its function as an arm of the party-state, working closely with local governments and factory managements, and often turning a blind eye to labour exploitation (A. Chan, 1993; Chen, 2003; Friedman and Lee, 2010). Absent the trade union, labour NGOs (LNGOs), which are the equivalent of worker centres in western countries, have emerged to assist individual workers to take on some of the labour protection tasks (Howell, 1995).

The southern province of Guangdong, just north of Hong Kong, was the first and remains the largest hub of global supply-chain manufacturing in China, and most of the LNGOs are concentrated there. As most of them try to avoid being monitored by the authorities, some are registered as businesses, community centres, occupational health and safety consultants, legal aid centres, or are not registered at all. Each of them usually has a staff of only a few people, depending on their ability to solicit foreign funding. Nonetheless, the local governments and trade unions regard them as potential instigators of instability and unrest among workers.

In light of foreign scholars' interest in the emergence of civil society in China, there is a 
growing body of literature on LNGOs. These writings tend to focus on two particular areas. The first is the LNGOs' relationship with the party-state - ranging from the latter's suspicion and hostility toward LNGOs to the ACFTU's more recent strategy of trying to co-opt them (Xu, 2013; Howell, 2015; Fu, 2016) and, if they do not comply, to suppress them. Official efforts to cow them into submission include intensifying harassment, interrogation and arrests (Cao, 2015; Franceschini and Nessosi, Forthcoming 2018). The government has also passed an Overseas Management Law that went into effect in 2017 (Ministry of Public Security, 2016), which strangles their overseas contacts and financial resources.

The second focus is related to a debate among researchers regarding the role LNGOs play in China's labour movement - whether they help to empower workers or whether their intervention is a hindrance to developing collective awareness. One academic, for instance, believes the Chinese LNGOs can take the place of trade unions in labour organising. ${ }^{1}$ Other academics have been sceptical of the LNGOs' efficacy in raising workers' consciousness, and argue instead that they have stunted the developmental process of a labour movement in China (e.g., Froissart, 2005). An extreme, negative position even castigates the LNGOs as an "anti-solidarity machine" (Lee and Shen, 2011). This critical view sees the LNGOs as helping to channel individual workers' grievances through the legal system, atomising and individualising workers, and retarding the development of their agency, initiative and participation in collective acts. This perspective sees the LNGOs as inadvertently assisting the authoritarian regime's hidden agenda to defuse workers' grievances, preventing them from gravitating toward class-based militant collective action. Another argument asserts that the LNGOs are ineffective, because workers mistrust the LNGOs and the LNGOs lack social capital (Franceschini, 2014).

One aspect that has not drawn much attention and that sheds light on the second debate is the changing relationship over time between foreign LNGOs, LNGOs in the People's Republic of China (PRC) and workers. Existing studies largely take a one-point-in-time approach, focusing on the time when a study is carried out, without taking into account the evolutionary process that preceded the present. This results in the construction of a static view of the relationship between LNGOs and workers. To draw any conclusions based on this approach, negatively or positively, ignores the dynamics of the changing relationship among actors, and runs the risk of bias. To rectify this, the article uses a historical approach that extends back three decades.

Against this backdrop the paper identifies three stages in the relationship between the two sets of LNGOs, and between the LNGOs and workers. In the first stage there was scant labour activism among the migrant workers in Guangdong. LNGOs operating out of Hong Kong established small LNGOs in Guangdong and developed a top-down strategy to attract and train potential workeractivists. Over time, these worker-activists began to organise their own LNGOs. This initial period of LNGO activism involved asymmetrical dependency relations between the fledgling PRC LNGOs and their foreign LNGO mentors and funders. This led eventually to a symbiotic relationship in which some of the Chinese LNGOs worked in a more equal partnership with Hong Kong and foreign funders. However, as the Chinese government has cracked down on PRC LNGOs in recent years, a third stage has emerged, in which some workers have had more success with autonomous organising among themselves. In a case that will be spotlighted - the organisation of a wave of protests and

${ }^{1}$ Pun Ngai's verbal presentation at a conference on "Comparison of Labour Disputes: Movements for Higher Wages and Better Working Conditions in China and Europe”, Vienna, 22-24 September 2011.

Global Labour Journal, 2018, 9(1), Page 2 
strikes in 2016 by Walmart workers across the country - the labour struggle was complicated and a schism developed within their movement when LNGOs became involved.

The paper will also touch on a very sensitive topic that has not been raised in studies of Chinese LNGOs - the issue of financial survival. Much has been written on how LNGOs try to survive politically by navigating strategically in an authoritarian regime: on their commitment, stoicism and courage to survive adversity. Unlike trade unions, they do not have a formal membership. Money is required to sustain the organisations and to carry out programmes. But money can define power relationships and generate conflicts between funders and recipients. Money also has the potential to corrupt. Rumours are rife within LNGO circles that some LNGOs have been corrupted. ${ }^{2}$ But publicly it is a hush-hush topic. In addition, now that the Chinese government has passed the Overseas NGO Management Law, the need for some LNGOs to run programmes that are in line with foreign funders' agendas has complicated the operations of those LNGOs, and occasionally has created tensions between these LNGOs and some of the workers.

\section{Research Methodology}

The information used in the historical section of this paper is drawn from a few dozen research visits to Hong Kong and China spread over the past three decades, and partly also from secondary publications and primary source materials. Knowledge about PRC LNGOs was also drawn from participating in workshops and conferences held in Hong Kong where LNGO staff from China presented reports and comments. The latest information on LNGOs in China was collected during three field visits in 2014, 2015 and 2016. The last visit was particularly relevant for gaining a better perspective on the LNGOs' situation after the December 2015 crackdown and the Walmart strike debacle. During these trips my interviews included five key activists heading five LNGOs. These interviews were recorded and transcribed verbatim. In those trips I also met with a number of Walmart workers in Shenzhen. Since mid-2016 I also began to frequently access Walmart workers' social media chat rooms, from which I developed a deeper understanding of the debates and conflicts among the key personalities involved in the Walmart labour protests as well as the relations between workers and LNGOs.

\section{The Global Labour NGO Chain and the Actors' Power Relationships}

Due to the authoritarian nature of the Chinese regime, the situation of LNGOs is unusual. It is not a standard case of locally funded labour centres providing services and helping workers to organise. It involves several types of LNGO actors, organised in a chain, each playing quite different roles. At the head of the chain are funders from the Global North. These include trade unions, foreign labour NGOs, foreign embassies and consulates, faith-based organisations, human rights groups, labour lawyer groups, etc. Due to the Chinese government's control, many of these funders do not operate inside China. Rather, they fund Hong Kong LNGOs, which then run programmes operated by

\footnotetext{
2 I personally encountered two cases of LNGO corruption when I was on their boards. In one case the amount was sizeable, yet this NGO continues to function today. I also have heard of a number of other cases through the years.
}

Global Labour Journal, 2018, 9(1), Page 3 
Chinese LNGOs at the coalface inside China. Some Hong Kong LNGOs have managed to set up offices inside China but have to remain low-key. They serve not only as distributors of funds to a number of Chinese LNGOs but also, just as importantly, as monitors to ensure that the funds are properly spent. They act as the liaisons between international funders and the fledgling independent labour movement inside China. ${ }^{3}$ In recent years the role of the Hong Kong LNGOs has diminished as more international funders began to establish direct contact with Chinese LNGOs.

\section{A Dependency Relationship: Hong Kong LNGOs and Chinese Migrant Workers}

Since 1997 Hong Kong has come under Chinese sovereignty, but the Chinese government continues to class Hong Kong LNGOs as foreign, similar to when Hong Kong was a British colony. Chinese NGOs and Chinese workers also regard them as foreign, as do the Hong Kong LNGOs themselves. The Hong Kong LNGOs therefore come under the sanctions of the new Overseas NGO Management Law. Paradoxically, since Hong Kong's people are considered by the PRC government as theirs, Hong Kongers are placed in an ambiguous citizenship status, relegating them to a vulnerable situation under China's suppressive regime. Hong Kong NGO staffers have to be extremely cautious today when working inside China.

After China's first export economic zone was established in Shenzhen in the 1980s, a large number of Hong Kong factory owners quickly set up factories there. Socially concerned political and labour activists in Hong Kong were the first to notice the mistreatment of migrant industrial workers in Shenzhen, which was far more severe than what owners would dare to do in Hong Kong (Lee, 1998). By the mid-1990s, some faith-based NGOs and youth-oriented NGOs in Hong Kong began to establish and fund labour NGOs in Shenzhen. The local Shenzhen government and the local official trade unions initially did not view these LNGOs staffed by a few young people as a challenge. The migrant workforce then was composed largely of poorly educated young women. Most of them were aged between eighteen and their early twenties or below minimum age, and most were housed in very crowded dormitories inside factory compounds. Wages were about a tenth of those in Hong Kong. Some workers could only afford to eat two meagre meals a day if they were to remit any money back home (A. Chan, 2001, 2002; Pun, 2005). They occupied the lowest rung of the social strata in Guangdong province. Most of them had never previously seen a city. Arriving for the first time in their late teens after a long journey on rickety, dirty long-distance buses, hauling their belongings in canvas bags - a few pieces of clothing, bedding, a tin mug and a wash basin - they were easily identifiable as migrants. China's household registration system deprived them of the right to be in the city unless they found an employer. When they were caught without the proper papers they could be rounded up, sent to overcrowded detention centres and shipped back to their home villages. Male migrants, profiled as trouble-makers, had difficulty finding employment in factories and were even more vulnerable. Some dared not venture into the streets before securing employment for fear of being caught by the police. In many ways, it resembled the pass system in South Africa under apartheid (Alexander and Chan, 2004).

Public discourse stamped migrant workers with names like "the tribe labouring for the capitalists", the "vulnerable groups" or the "peasant-workers". All these labels consigned them to the status of victimhood in the new age of Chinese economic development. To an urban Chinese

${ }^{3}$ Though writings about LNGOs in China tend to neglect the pioneering role of Hong Kong LNGOs, at least two scholars have acknowledged their contribution (C. Chan, 2012; Xu, 2013).

Global Labour Journal, 2018, 9(1), Page 4 
resident, the workers from the countryside were either to be pitied or were pariahs to be despised and abused. The migrant workers themselves accepted the labels, lamenting that they were victims of their own fate. Hong Kong LNGOs saw their mission as to slowly alter the mindset of the young migrant workers by first teaching them about the laws and their rights, how to read pay stubs, how to seek redress for owed wages or legal compensation for injuries. The LNGOs' staff sought out those workers who showed activist potential to raise their labour rights awareness. The authorities were tolerant as long as the LNGOs steered away from discussing topics such as free trade unionism and strikes.

\section{From an Asymmetrical to a More Balanced Partnership: Chinese and Hong Kong LNGOs}

The Hong Kong LNGOs' patient efforts paid off within about a decade, by the turn of the new millennium. Quite a number of LNGO staff had been trained from among the Chinese labour activists in Guangdong, who gradually set up their own LNGOs affiliated with the ones in Hong Kong. Quite a few of the founders of today's Chinese LNGOs came from that first crop of labour activists. Some home-grown Chinese LNGOs were founded by Chinese workers themselves. These were mostly former worker-activists, quite a number of them in their late twenties and early thirties. A sizeable number, especially men, had worked in jobs susceptible to industrial accidents, and after losing fingers, hands or arms in metal-works factories, they had gained experience fighting for compensation. The protracted legal process turned them into labour law experts and hardened them to fight back, and they began helping other workers gain compensation through the court system. There are many hundreds of these "barefoot lawyers" working in LNGOs that are essentially paralegal aid firms. The LNGOs' programmes usually consist of legal consultation, dissemination of legal knowledge, and helping workers seek compensation for industrial injuries through legal suits and training in occupational safety and health. Such activities required external funding, and Hong Kong LNGOs continued to serve as funding conduits into China.

With time, the indigenous LNGOs became increasingly independent of the Hong Kong LNGOs, especially if they were able to receive foreign funding directly from international funders. The umbilical cords, however, were not totally severed. On both sides of the border, some LNGOs gradually entered into symbiotic relationships. Chinese workers and indigenous LNGO staff lacked any foreign-language ability to communicate with the outside world and needed to rely on their Hong Kong counterparts. Those without funding relied on Hong Kong LNGOs to help them understand how foreign funding systems work, how to draft programme applications and reports to funders, or to participate in international conferences and study tours. Hong Kong LNGOs, for their part, being confined in a grey zone, could no longer openly operate in China except through Chinese LNGOs.

As a result, a mix of relationships emerged depending on whether the Chinese LNGOs still relied on funding coming through Hong Kong. Those that had independent sources became more autonomous, whereas others had to maintain a more dependent relationship. Increasingly, Hong Kong LNGOs that trust and respect their Chinese counterparts see themselves as partners and see their role today as facilitators of the labour movement inside China. But those that would not relinquish their patronage relationship continue to use their own access to funds to intervene in and direct the activities of their Chinese counterparts according to their own or foreign funders' agendas. As will be seen later, this has introduced contention between workers and LNGOs. 


\section{Workers' Collective Actions Superseding LNGOs' Agendas}

The birth of a new phase of China's labour movement in 2006 was signalled by the emergence in the midst of a strike of an elected workplace trade union in a small electronics company, Ole Wolff Electronics, in Yantai city, Shandong province. The husband of one of the strikers, an electrician named Zhang Jun, who was self-educated in labour laws, helped the workers struggle through a formidable four-year journey to keep their union from being annihilated. Though it involved fewer than a hundred workers, to my mind it was a significant incident for a number of reasons. First, the workers had had no prior contact with any LNGOs, nor did Zhang Jun. It was a protest driven by workers' own agency. As far as I am aware, the Ole Wolff workplace trade union was the first one that was set up as a result of a strike. It was also the first workplace trade union established by workers and then recognised by the ACFTU (A. Chan, 2015: 105-108). The birth of the Ole Wolff Trade Union marked the beginning of a stage where some Chinese factory workers attained labour subjectivity (Globalization Monitor, 2008). In subsequent years, workers' protests occasionally included a demand to elect trade union branch leaders of their own choice in addition to material demands regarding back pay, wages and entitlements (C. Chan, 2010; A. Chan, 2015; C. Chan and Hui, 2017). Since trade union branch elections are prescribed by law, albeit rarely held, local official trade unions grudgingly sometimes would permit such elections, though they normally tried to manipulate them in a two-stage election process to make sure they could continue to assert control over the newly elected union branches. One excellent example was the Nanhai Honda strike of 2010 in Guangdong in which the post-strike union election was manipulated by management and the official union (C. Chan and Hui, 2012).

An increasing number of strikes in the first decade of the 2000 s were self-initiated by workers, not in any way related to LNGOs, such as the Yue Yuen footwear company strike in Guangdong in 2014 and 2015 involving 40000 workers (Hui and Timmons, 2015). At Yue Yuen and elsewhere, a driver behind the strikes was the demand that employers pay years of unpaid or underpaid contributions to workers' government-sponsored old-age-pension funds. Twenty some years ago when migrant workers were almost all in their twenties, they were not particularly concerned when their employers did not make this legally mandatory contribution, because they themselves were reluctant to contribute their share to old-age social security. But in many industries today, part of the workforce is in their forties and even fifties. Decades of heavy and debilitating labour is taking a toll on their strength and health, and they are worried about life after retirement.

Their fear is exacerbated by the recent economic slowdown in Guangdong that is causing a large number of factory relocations and closures. Unconscionable employers have been packing up and leaving workers stranded without settling unpaid wages, social-security contributions and severance payments. In 2014, this was the catalyst that instigated the strike of 40000 workers of Yue Yuen, the world's biggest footwear company, where workers stopped work for about twenty days. The strike was initiated by older workers. Taking militant action was their last hope to pre-empt the company from running away with their "blood and sweat money". Through the years such workers have gained experience and confidence as they have matured. Whereas in earlier decades almost all the migrant workers were in their twenties and there was a very high turnover rate, which limited any accrual of labour-protest experience and lessons learned, today both workers and LNGO staff are aging. The heads of LNGOs tend to be at least forty years old or even in their fifties.

The willingness of some of the workers to take risks has outpaced the LNGOs' consciousness-

Global Labour Journal, 2018, 9(1), Page 6 
raising agenda, which is limited by the government's watchful insistence on moderation and legal compliance. It is often only after strikes have started that LNGO staff rush to the sites in the hope of helping strikers to better get organised and to advise on how to negotiate. But they are in no position to mobilise thousands of workers to go on strike or to march onto the streets. ${ }^{4}$ The two Yue Yuen strikes of 2014 (Lau, 2014) and 2015 (Hui and Timmons, 2015) are evidence that the workers themselves are capable of staging massive collective actions.

\section{State Suppression Breeds Defiance}

Despite the fact that Chinese LNGOs do not have the capacity to organise strikes, the authorities increasingly do not regard them as benign. They fear that LNGOs are potential instigators of instability. To some extent this is true, since the LNGOs' years of work has helped raise labour activists' awareness of their legal rights. The PRC LNGOs bear the brunt of the authorities' antagonism. To ensure that the LNGOs do not overstep the line, the authorities periodically harass them to alert them to their vulnerability. In 2012 local governments in Guangdong province tightened the screws on them by launching a new strategy - putting pressure on landlords to evict their LNGO tenants. But after having been evicted half a dozen times, the LNGOs became blasé about it. As one LNGO staff member told me in 2014, "We've become used to it. Before it took us several days to pack up, now we just buy a few pieces of old furniture and we can move in one day." Instead of abandoning their work, the LNGOs continue with their activities, unintimidated. They have also become used to being "invited to have tea" with their official interlocutors. These polite meetings have become a kind of game. Each side knows what the other knows, but pretends otherwise. One LNGO staff person in 2016 even saw it as a positive exercise:

It's not that we have to report everything to the authorities, but it is good to let them know what you are doing since they know all about your activities anyway. They know you are not going against them and as a result they do not put more pressure on us. I think this kind of dialogue is necessary (Franceschini and Nesossi, Forthcoming 2018).

However, there are times when the police treat them with a heavy hand, employing thugs to turn up at an LNGO's office to smash furniture and ransack the office, intimidate them or even beat them up (Wen, 2012; Ong, Forthcoming 2018).

Hong Kong LNGOs for their part do not face harassment within Hong Kong, even though Hong Kong itself is experiencing increasing threats to political and civil liberties. Hong Kong LNGOs continue to act quietly as a conduit transferring foreign funds to Chinese labour NGOs, publicising Chinese workers' struggles to the international labour community, and providing a safe haven where Chinese LNGO staff, on day trips to Hong Kong, can openly air their views and exchange experiences and ideas. On one such occasion in 2014, I observed a workshop held in Hong Kong where participants from a dozen Chinese LNGOs engaged in sophisticated analyses and

${ }^{4}$ The spontaneity of the strikes and how LNGO staff rushed around on a daily basis to strike sites during the two years before the 2015 crackdown is depicted in an interesting documentary, We the Workers, directed by Wenhai Wang, a PRC film-maker who lived with LNGO employees for some months. The footage I saw was a three-hour-long unedited version.

Global Labour Journal, 2018, 9(1), Page 7 
debates about the increasingly suppressive political climate in China. The way they spoke showed they were no longer quiet recipients of foreign wisdom. Since they are the ones who bear the consequences of suppression, they were devising contingency plans to protect themselves, if and when the need arose. At that meeting, before commencing a discussion on strategies in the face of a crackdown, they all removed the SIM cards from their cell phones. The discussion ended in a consensus that those who were timid should be allowed to leave the movement and those who chose to stay should be prepared to be arrested.

\section{The Crackdown and Foreign LNGOs}

Since President Xi Jinping came to power in 2013, an overall political tightening up in China has underpinned the repression of any potential labour unrest. He and other leaders strongly believe that contacts with foreign NGOs from democratic societies are subversive, spreading an ideology that instigates social instability and encourages a "colour revolution" (Shi-Kupfer and Lang, 2017; Fu and Distelhorst, 2018). The new Overseas NGO Management Law was enacted to prevent democratic ideas from spreading into China.

A year before the law was passed, there were already a series of crackdowns on various types of NGOs. For instance, in May 2015 women activists in different cities were arrested at the same time and detained for five weeks merely for trying to hand out leaflets against sexual harassment in public transport (Branigan, 2015). Two months later more than two hundred prominent humanrights lawyers were detained (Leavenworth, 2016). In January 2016, a Swedish national working for a Swedish NGO in Beijing, which trains civil and human rights lawyers, was apprehended for providing funding and was released only after he recanted his wrong-doing on Chinese national television (Phillips and Holmes, 2016). His arrest was interpreted as a warning that the government would seriously enforce the new overseas NGO law once it became effective.

A crackdown on LNGO staffers came in December 2015. Initially it involved the arrest and detention of eleven staff members from various LNGOs in Guangdong. Four, and then later two others were released without charge, but five were detained for disturbing public order (Chen, 2015; Phillips, 2015). Why these five? A common denominator they shared is that their main source of funding and connections can be traced to the most active and biggest of the Chinese labour NGOs in Guangdong, the Panyu Migrant Workers Service Centre, whose source of funding in turn came from the biggest and best-funded LNGO in Hong Kong - China Labour Bulletin (CLB) (CLB, 2017). About three weeks after the crackdown, a lengthy and detailed article in the Communist Party's newspaper, People's Daily, charged that the director of the Panyu Centre, Zeng Feiyang, received significant funding from CLB and was acting under its direction (Zhang, 2015).

A brief aside about China Labour Bulletin is in order here. CLB is an anomaly among the LNGOs in Hong Kong. Though located in Hong Kong, CLB is neither headed nor staffed by Hong Kongers. It was founded by Han Dongfang, a former Beijing worker who famously briefly organised an autonomous trade union at the Tiananmen Square protests in 1989. He has been in exile in Hong Kong since 1994, and has received many awards and a large amount of funding from various Western governments, international trade unions and other organisations (Wikipedia, 2017). Han presented himself as an alternative to the ACFTU as representing Chinese workers and was recognised as such internationally, enjoying a high status in parts of the international labour 
community. Compared to other Hong Kong LNGOs, CLB has a sizeable number of staff in Hong Kong and distributes funds to a number of PRC LNGOs to run programmes. Since about 2010 Han has been pushing his PRC partners to carry out CLB's project to promote collective bargaining. The Chinese authorities have been aware of these activities, but until 2015 allowed them to continue with half-closed eyes.

In 2015, three months after the release of the second draft of the law on international NGOs, when the NGO world was jittery about an unpredictable future, Han delivered a statement at a hearing of the United States (US) House Foreign Affairs Committee's Subcommittee on Asia and the Pacific. In this, he surprisingly stated, "We have developed a strong network of labour NGOs inside China who are highly committed to promoting a workplace collective bargaining system. In the last five years, we have now been involved in more than 70 collective bargaining cases" (Han, 2015: 7). A public statement at such a high-profile occasion, flaunting the scale and success of his organising activities inside China, and at a time when the foreign NGO law was being drafted, was certain to draw the close attention of the Chinese government and the ACFTU. To my mind, it is not farfetched to draw a connection between Han's speech in the US and the arrests of the five staffers of Chinese labour NGOs that had been directly or indirectly receiving his funding. The People's Daily article recounted in detail that Zeng Feiyang had been receiving more than US\$100 000 a year from CLB through complicated covert banking arrangements. In an attempt to discredit Zeng, the article also alleged that Zeng has been dipping into the till and living a lifestyle above his means (Zhang, 2015).

Han Dongfang (2016: n.p.) responded with an open letter that did not deny CLB's financial aid. In fact, Han wrote that CLB "has been assisting workers who have spontaneously organized strikes to elect workers' representatives to engage in collective bargaining". Surprisingly, he also disclosed that Zeng had asked Han not to send him money because the pressure from the authorities was mounting, and that Zeng had said it would be better if he himself contacted the financial sponsors directly. Indeed, within the LNGO circle there also have been rumours that CLB's money was too risky and that CLB has been too controlling. Some of the LNGOs that received CLB money had to trade autonomy for the needed money. My interviews at four LNGOs in Guangdong at the end of 2016 confirmed that most of the PRC LNGOs that had received CLB funding had been complaining about the lack of autonomy.

When asked what they thought of Han Dongfang's speech in the US and his open letter to People's Daily, three interviewees from different NGO groups explained that these actions were detrimental to the LNGOs in China. One of them, for instance, said,

After reading that open letter by Han we colleagues in the mainland thought the letter did not protect us at all. On the contrary it has a negative effect. It pushes us to a higher level of risk.... He might have his own reasons in doing this.... Yes, true, the authorities know [about the money], but you don't talk about it or write about it openly like this. ${ }^{5}$

In the next section I shall use the case of Walmart store workers' struggle against Walmart's

\footnotetext{
5 This information derives from two research trips to Guangdong province in November and December 2016, when I separately interviewed four LNGO staff members and several individuals (including two workers) who have been closely involved in or are active in the movement.
} 
introduction of a new "flexible" work-hour system that was markedly detrimental to the workforce. There are a number of reasons why this struggle serves as a good case to illustrate the emergence of labour agency among Chinese workers that resulted in a new relationship of distrust between some LNGOs and workers. This struggle is also significant in that it involved 20000 workers spread over several hundred workplaces organised via social media platforms. The enormous pressures converging on the various actors involved in the struggle also forced the tensions brewing among them into an unprecedented open confrontation in the second half of 2016.

\section{The 2016 Walmart Labour Struggle ${ }^{6}$}

In 2006 the ACF'TU was pressured by the Chinese Communist Party to try to contain workers' protests, which had been on the rise. The ACFTU experimented with using the best-known foreign company in China to set an example. Contrary to the ACFTU's previous practices, the union federation organised Walmart workers "underground" by quietly approaching them outside of work hours. In a matter of about two months democratically elected union branches were established in about fifteen Walmart stores without Walmart's knowledge. After the ACFTU publicly announced this fait accompli, Walmart cut a deal with more conservative officials of the union federation that allowed Walmart management to control the union branches (A. Chan, 2011), and the union signed so-called "collective agreements" in the name of the workers. Over 400 Chinese Walmart stores today have workplace unions, though all of them are yellow unions (Unger, Beaumont and Chan, 2011). But this has an unintended consequence, in that it gives Walmart workers opportunities to register as candidates to compete in union branch elections and thus publicise their views, even though the results of almost all the elections are predetermined.

When Walmart's profits in China began to falter due to over-expansion, the company began manipulating wage packages, intensifying workloads, shortening work hours, cutting overtime to avoid paying overtime premiums, increasing the percentage of part-timers, laying off workers, and closing some stores. These measures have been causing grave dissatisfaction among employees (He and Liu, 2013; Pringle and Crothall, 2017).

In 2014, two Walmart workers in two different provinces set up an on-line forum called the Walmart Chinese Workers' Association (WCWA) to reach out to Walmart workers across China. The worker in Shenzhen, Zhang Liya, had tried to run for trade union chair at his store in 2015. The other worker, Zhang Jun in Yantai, Shandong Province, was the electrician who had organised the Ole Wolff trade union. Because of the active role he had played at Ole Wolff, he had lost his job and was blacklisted. Since then he had spent his time helping workers with online legal advice until, with difficulty, he found a low-paying job at his local Walmart store. In the four and half years that he was a Walmart worker, whenever he had a chance to travel to other cities he would visit Walmart stores in the hope of meeting some activists. That was how the two Zhangs met. Both therefore have

\footnotetext{
${ }^{6}$ From here onwards a large amount of information on the Walmart workers' struggle is based on closely following blogs, microblogs, QQ and Wechat social media among Walmart workers. It is not possible to provide citations to all of them. Notably, too, some sources of information cannot be revealed without endangering activists inside China who spoke with me or have communicated with me through social media.

${ }^{7}$ In a very rare case, Li and Liu (2016) gave a detailed account of one Walmart store where the more openminded management allowed democratic election of the trade union chair in 2013.
} 
behind them a history of struggle against management. In the beginning they had only modest expectations of WCWA. It was to be no more than an online platform where Walmart workers could exchange experiences, air grievances and provide mutual moral support (WCWA, 2014). At the very end of 2015 Zhang Jun had to leave Walmart under pressure (while his wife continued to work there) and Zhang Liya was fired five months later. Though no longer Walmart workers, both continued to run WCWA.

In mid-May 2016, Walmart announced it was switching the regular work hours to an extremely flexible work schedule in which store workers frequently could be on call at irregular hours without overtime pay. This caused consternation among the workers. WCWA stirred into action. Zhang Jun posted a number of open letters explaining the serious implications if this new system were implemented. Suddenly WCWA's on-line membership jumped to 10000 and later to 20 000. WCWA became China's largest self-organised worker network across multiple workplaces under one employer in the private sector.

Drawing from his past experience with the ACFTU ten years earlier in the Ole Wolff Electronics strike, Zhang Jun's strategy was to hold the ACFTU and the local government labour bureaus responsible to rein in Walmart. WCWA activists sent local unions and government offices open letters and visited their offices. Having exhausted all possible channels to stop Walmart's coercive measures to enforce the new work-hour system, Walmart workers in Nanchang City, Jiangxi province, declared that they refused to sign new contracts to be paid by the new wage system. They went on strike on 1 July 2016. Supportive messages from WCWA members poured in. The Nanchang store was hailed as a model by the aggrieved Walmart workers. This is the very Walmart store where ten years earlier its new democratically elected trade union chair was fired for openly refusing to sign a so-called collective agreement drawn up by Walmart that would adversely affect workers (A. Chan, 2011). Soon workers at three other stores in other cities followed suit and went on strike. WCWA became the organising hub and morale booster across the country. WCWA's leaders were convinced Walmart China and the local trade unions were terribly nervous that the strikes would spread, and that it was likely Walmart would have to compromise.

In the midst of this upswing in Walmart worker activism, a well-known labour lawyer, Duan Yi, flew into Nanchang from Shenzhen and started advising the workers to stop the strike. He reportedly advised that, according to the law, to go on strike for three days would increase the chance of workers losing their lawsuits. Workers were divided over whether to continue the strike and finally accepted Duan's advice. Once the strike stopped, Walmart retaliated. In the following half-year it intimidated, harassed and fired several dozen of the most activist workers.

In late July 2016, the People's Daily issued a public statement declaring that retail stores are not eligible to use Walmart's work-hour system. But the article did not mention Walmart by name (ACFTU, 2016). A month later, the Guangdong Provincial Federation of Trade Unions (2016) released a statement to the same effect, this time specifically directed at Walmart. But the subprovincial local unions, which are controlled by local governments eager to attract and retain investors, ignored the announcement. This allowed Walmart to continue to put immense pressure on workers. Many workers capitulated and signed the consent forms. WCWA tried to get in touch with international trade unions and labour communities, especially with Our Walmart in the US. It was the first time that Chinese workers took the initiative to seek international solidarity (Bose, 2016). 


\section{Split in the Walmart Movement}

At about the same time that Duan Yi became involved in the Walmart protests, Zhang Zhiru, the head of another Chinese LNGO, Chunfeng (Spring Wind) in Shenzhen, entered the scene. ${ }^{8}$ One of Chunfeng's funders is CLB. In WCWA's chat rooms, Duan began denouncing the two founders of WCWA as being too timid and cautious, neglecting workers' wishes to increase wages, and not organising collective bargaining, which he argued was the essential step forward. He also argued that WCWA should immediately hold a democratic nationwide election to form a structured organisation with a coordinating committee.

On the surface, the disagreement seemed to be over campaign strategies. Zhang Jun's position was to minimise confrontation with the government and official union authorities at this time of struggling against Walmart. He argued that any attempt to establish any kind of formal organisation beyond a social media platform would invite official suppression. Zhang Zhiru argued that an aggressive strategy could force Walmart to enter into collective bargaining. Zhang Zhiru's declarations split the WCWA. He started to provide training sessions in collective bargaining in Shenzhen. ${ }^{9}$

Open confrontations erupted in the chat rooms between the two sides, with a continuous exchange of venomous accusations of greed, official collusion and corruption. This threw Walmart workers into confusion, and participation in the WCWA network went into freefall. Taking advantage of this, Walmart went on the offensive, coercing workers to sign the new contract and lashing out at recalcitrant workers who refused. The retaliation has been relentless. Activists in a number of stores who urged their co-workers not to sign were harassed and fired one by one. Local official unions, local governments and the higher echelons of the ACFTU have not lifted a finger to help the workers despite the initial announcements that Walmart was breaching the law. The Shenzhen trade union in Guangdong was officious, dismissive and sarcastic when workers came to seek support. Take the case of one of the most active of the Walmart workers in Shenzhen, who had once tried to run as a candidate for the union committee in a trade union branch election. She had written to and gone to various government agencies a number of times. Now she went to the Shenzhen trade union to seek help and recorded how she was berated by a high-level Shenzhen union official:

All your trivial complaints amount to saying you are dissatisfied with Walmart and dissatisfied with the union. What do you have in mind to do? You want to struggle against the company to the very end? ... You are just one individual. Listen to me, those people in cyberspace can't help you. Actually, we are willing to help you, but you need to behave yourself. You have a long conflict with the company. You should change your attitude. The company has a normal management system. You should maintain a cooperative attitude with the company.... I did not say what you wrote is incorrect... But no one can help you when you hold onto this confrontational attitude of yours. If you were my sister, I would tell you off: 'serves you right'. If you were my daughter, I'd smack you. If

${ }^{8}$ I interviewed Zhang Zhiru at his office in 2016.

9 This information is taken from the transcript of a cell phone recording regarding this training http://blog.sina.com.cn/s/blog 165cb76be0102wrz3.html [accessed 4 August 2017] (in Chinese) - which took place on 12 August 2016.

Global Labour Journal, 2018, 9(1), Page 12 
you consider things from the vantage point of the workers, then you would not oppose Walmart's work hour system. ${ }^{10}$

He became impatient and ordered a security guard to escort her out.

With the movement dissipating and no support from the ACFTU forthcoming, the participants retreated to a low-key phase. WCWA's main task now was focused on helping fired activists with their personal litigation against Walmart. Unemployed, these workers are desperate to get some compensation, but just as importantly they want to show Walmart that they will not so easily give in. Each case of litigation costs from one month to three months of a worker's salary (3 000 to $10000 \mathrm{RMB}$ ), so WCWA launched a crowd-donation campaign and successfully raised 50000 RMB, and lawyers' fees have been waived by pro bono lawyers.

Meanwhile a bitter disagreement boiled over between Zhang Jun and the co-founder of WCWA, Zhang Liya, who had joined Duan Yi's staff after losing his job. At the same time, Zhang Zhiru increased his involvement and joined hands with Duan Yi, determined to gain sway over WCWA and to side-line Zhang Jun's influence. I was reading the Wechat feeds on a daily basis as the vitriolic exchanges between the two camps degenerated into fake news and vicious personal attacks (Gong, 2016).

In mid-2017 Duan Yi and Zhang Zhiru's group revived the call for an election to set up a formal organisation. The election, using SMS, took place in May 2017, and a new association was declared established and was given the name Walmart Workers Association (China) (WWA(C)). It was announced that Zhang Liya had been democratically elected to head WWA(C)'s executive committee. The invective between WCWA and WWA(C) had not ceased at the time of writing this paper. As this infighting continues, the two years of struggle against Walmart has failed to stop Walmart from implementing the new work-hour system. Dozens have lost their jobs. But is it all doom and gloom?

Looking on the brighter side, some positive developments have emerged out of these two years. A new crop of labour activists has been cultivated. They have built a nationwide network which, if maintained, can be mobilised into action in the next round of struggle. They have gained much knowledge and experience, and learned not only how best to fight against one employer, but also the importance of organising across workplaces.

At the time when activists in Walmart were plunged into an intense fight against daily harassment by management, some of them have gradually become more aware of their own agency. As their beset movement enters a stage of litigation, they exchange information and reflect in a postmortem analysis on the twists and turns of the failed struggle. Should they have continued the strike wave and not heeded Duan Yi's advice? Can a social media platform alone sustain a movement? Would it be possible to hold a democratic election by workers in so many workplaces? Would forming a structured organisation attract government repression? Searching for answers to such questions and a range of other questions (Qiu, 2017) has led some of them to turn to discussing what I earlier coined in the paper as "the global labour NGO chain". They are cognisant that there is a bigger world of labour out there that can affect and help their cause and that they can potentially affect.

10 This excerpt is taken from a transcript recorded on 18 September 2016. 


\section{Conclusion}

The first half of this paper has recounted the changing relationship between foreign LNGOs, Chinese LNGOs and Chinese workers over the past two and a half decades. The intention has been to introduce a historical perspective on the role of LNGOs in China's labour movement in the growing non-state sector. As has been seen, the relationship is not static. It has changed from one of workers' dependency on LNGOs in an asymmetrical relationship to one of partnership, and more recently some of the activist Walmart workers rejected an LNGO when they felt the latter's interests diverged from theirs. Both workers and LNGOs are subject to the danger of suppression, and they may choose different strategies in order to survive. The case of the struggle by Walmart workers is an example. Workers may want to take a less confrontational stance, avoid breaching any laws and retreat when the possibility of being suppressed is imminent. Some LNGOs, both inside and outside China, desperate to survive financially, are eager to accommodate to foreign funders' wishes to get workers to set up more formal organisational structures to collectively bargain. To the authorities and the ACFTU, LNGOs' attempts to organise workers to engage in bargaining is an aggressive challenge to its monopolistic power. In fact, in an interview I held in early 2017 with a liberal-minded trade union official, he said he had met with Zeng Feiyang and had given him friendly advice not to accept CLB's funds or to raise the banner of collective bargaining. When Zeng ignored the advice and was arrested, he was made into a publicised national example of what the Chinese authorities call "negative education material".

The view of Zhang Jun and a number of other Walmart worker activists was that when Zhang Zhiru pushed the Walmart workers to organise into a formal structure he was overstepping the authorities' red line. If this scenario is correct, Zhang Zhiru was fortunate that the movement imploded, and the authorities and the trade union let Walmart do the job of suppression.

The Walmart incident is symptomatic of the divergent interests that can emerge between workers and some of the more activist LNGOs. For the first time, questions have arisen as to what extent LNGOs should be involved in labour protests. To what extent should they influence a strike? Are theirs and workers' interests necessarily the same? To reflective LNGO staff, these are ethical issues that have preoccupied some of them. As one said to me in late 2016, "We have to redefine our role in the movement."

There is also the question of whether social media can be an organising vehicle for workers, especially when resistance involves a large number of workplaces. Organising takes time and effort at one workplace, let alone across a multi-workplace platform. The two WCWA founders set up the association without even a programme, but when Walmart suddenly imposed the new work-hour system on the workers, WCWA was forced to react. It was a spontaneous response to Walmart's new exploitative measure.

At the same time, in a growing number of incidents around China workers have begun, on their own, to demand better working conditions and their legal entitlements. The Walmart case is yet another piece of evidence that Chinese migrant workers are increasingly willing to confront employers. As reflected in the 20000 Walmart store workers who participated in the WCWA chat rooms, the consciousness of some of the migrant workers in China has risen (Franceschini, Siu and Chan, 2016). The reasons for this growing awareness are multiple - demographic (an aging workforce), technological (IT revolution; cell phones), personal development (through accumulated 
experience), and legalistic (increasingly litigious) - nourishing labour agency in a process of maturation. Despite the negative outcome of the Walmart case, it provides evidence that workers have the capacity to become an active force, willing to confront employers in more than the previous phenomenon of spontaneous wildcat protests.

As was observed in comments on WCWA's online forum, international help and solidarity actions are welcomed and can help indirectly to strengthen the movement, but some of the workers in China are no longer in a state of tutelage and do not want outsiders to force their agendas on them. For the time being, most strikes are still isolated at single workplaces rather than coordinated. But Walmart workers may well be at the forefront of a new stage in which protests and strike actions are coordinated across distances using the Internet and an explosion in the number of chat rooms. It may not take long for better-organised labour protests to emerge in the manufacturing sector, coordinating multiple workplace protests. If this happens on a large scale it may grow violent, unless local authorities have a change of mind and begin to address workers' grievances.

One phenomenon to note vis-à-vis the Walmart case is that the authorities have not been fiercely repressive. There is room for workers to stage protest actions within an ill-defined red line understood by the workers and LNGOs. Zhang Zhiru, for instance, was not arrested. Zeng Feiyang, the main target of the crackdown on LNGOs, was released from detention and given a three-year suspended sentence. Of those arrested at the end of 2015, all were released except for one of Zeng's staff who received a twenty-one-month jail sentence (Lai, 2016). His colleagues think this was because it was the second time he had been arrested while still under a suspended sentence. Indeed, at the height of the recent Walmart campaign, local authorities told one of the organisers that he could organise the Walmart workers as long as he did not get involved with any foreign institutions. That is, while allowing workers some space, the space given to LNGOs has been restricted in that without foreign funding they may ultimately have to close down or, alternatively, join the NGOs that have been co-opted by the local state in what Jude Howell (2015) describes as "welfarist incorporations", confining their activities to delivering social services (Spires, 2011). This in turn would mean workers would have to rely on their own resources and experience.

\section{REFERENCES}

ACFTU Law Department (2016) Before Implementing the Generalized Work Hour System, Consultation with the Trade Union and Labour Force is Required [in Chinese]. Guangdong Federation of Trade Unions, 27 July 2016. Available at http://www.gdftu.org.cn/xw/rd/201607/t20160727_784091.htm [accessed 3 August 2017].

Alexander, P. and A. Chan (2004) Does China have an Apartheid Pass System? Journal of Ethnic and Migration Studies, 30(4): 609-629.

Branigan, T. (2015) Five Chinese Feminists Held Over International Women's Day Plans. The Guardian, 13 March.

Bose, N. (2016) Exclusive: U.S. and Chinese Labour Groups Collaborated before China Wal-Mart Strikes. Reuters, 18 July. Available at http://www.reuters.com/article/us-walmart-china-idUSKCNOZYOSV [accessed 30 June 3017].

Cao, Y. (2015) Chinese Authorities Orchestrate Surprise Raid of Labor NGOs in Guangdong, Arresting Leaders. Available at https://chinachange.org/2015/12/10/chinese-authorities-orchestrate-surprise-raid-of-labor-ngos-inguangdong-arresting-leaders [accessed 28 June 2017]. 
Chan, A. (1993) Revolution or Corporatism? Workers and Trade Unions in Post-Mao China. The Australian Journal of Chinese Affairs, 29: 31-61.

Chan, A. (2001) China's Workers under Assault: The Exploitation of Labor in a Globalizing Economy. Armonk, NY: ME Sharpe.

Chan, A. (2002) The Culture of Survival: Lives of Migrant Workers through the Prism of Private Letters. In Popular China: Unofficial Culture in a Globalizing Society, edited by P. Link, R. Madsen and P. Pickowicz. Boulder, CO: Rowman \& Littlefield.

Chan, A. (2011) Unionizing Walmart Stores. In Walmart in China, edited by A. Chan. Ithaca, NY: Cornell/ILR Press.

Chan, A. (2015) Trade Union Elections at Foreign-Owned Chinese Factories. China: An International Journal, 13(3): 94-113.

Chan, A. and K. Siu (2012) Chinese Migrant Workers: Factors Constraining the Emergence of Class Consciousness. In China's Peasants and Workers: Changing Class Identities, edited by B. Carrillo and D.S.G. Goodman. London: Edward Elgar.

Chan, C.K.C. (2010) The Challenge of Labour in China: Strikes and the Changing Labour Regime in Global Factories. Oxford: Routledge.

Chan, C.K.C. (2012) Community-based Organizations for Migrant Workers' Rights: The Emergence of Labour NGOs in China. Community Development Journal, 48(1): 6-22.

Chan, C.K.C. and E. Hui (2012) The Dynamics and Dilemmas of Workplace Trade Union Reform in China: The Case of the Honda Workers' Strike. Journal of Industrial Relations, 54(5): 653-668.

Chan, C.K.C. and E. Hui (2017) Bringing Class Struggles Back: A Marxian Analysis of the State and Class Relations in China. Globalizations, 14(2): 232-244.

Chen, F. (2003) Between the State and Labour: The Conflict of Chinese Trade Unions' Double Identity in Market Reform. The China Quarterly, 176: 1006-1028.

Chen, M. (2015) Seven Worker-Activists Involved in the Independent Labor Organizations Known as 'Worker Centres' have been Arrested. The Nation, 18 December. Available at http://www.thenation.com/article/chinas-latest-crackdown-on-workers-is-unprecedented/ [accessed 1 January 2016].

China Labour Bulletin (CLB) (2017) Available at http://www.clb.org.hk/ [accessed 6 August 2017].

Franceschini, I. (2014) Labour NGOs in China: A Real Force for Political Change? The China Quarterly, 218: 474-492.

Franceschini, I and E. Nesossi (Forthcoming 2018) State Repression of Chinese Labor NGOs: A Chilling Effect? The China Journal, no. 80.

Franceschini, I., K. Siu and A Chan (2016) The "Rights Awakening" of Chinese Migrant Workers: Beyond the Generational Perspective. Critical Asian Studies, 48(3): 422-442.

Friedman, E. and C.K. Lee (2010) Remaking the World of Chinese Labour: A 30-year Retrospective. British Journal of Industrial Relations, 48(3): 507-533.

Froissart, C. (2005) The Rise of Social Movements among Migrant Workers. Uncertain Strivings for Autonomy. China Perspectives, 61: 30-40.

Fu, D. (2017) Fragmented Control: Governing Contentious Labor Organizations in China. Governance, 30(3): 445-462.

Fu, D. and G. Distelhorst (2018) Grassroots Participation and Repression under Hu Jintao and Xi Jinping. The China Journal, $79(1):$ 100-122.

Global Labour Journal, 2018, 9(1), Page 16 
Globalization Monitor (2008) The Ole Wolff Workplace Union. Available at http://www.globalmon.org.hk/labor-rights/ole-wolff-workplace-union [accessed 29 June 2017].

Gong, Nu (2016) Walmart Worker Rights Protection has Reached a Critical Stage; Oppose Worker Sell Outs, Clarify Divided Opinions in Strategies and Protect Workers' Solidarity. Youth Spark [in Chinese], 29 July 2016. Available at http://www.youth-sparks.com/bbs/viewthread.php?action=printable\&tid=4639 [accessed 6 August 2017].

Guangdong Provincial Federation of Trade Unions (2016) Guangdong Provincial Trade Union: Against Walmart Using the Generalized Work-Hour System for All its Workers [in Chinese]. Southern Daily, 3 August 2016. Available at http://news.xinhuanet.com/fortune/2016-08/03/c_129201104.htm [accessed 3 August 2017]

Han, D. (2015) China's Rise: The Strategic Impact of its Economic and Military Growth. US House Foreign Affairs Committee, Subcommittee Hearing. Available at https:/ / foreignaffairs.house.gov/hearing/subcommittee-hearing-chinas-rise-the-strategic-impact-of-itseconomic-and-military-growth/ [accessed 30 June, 2017].

He, Y. and J. Liu (2013) Investigating the Shenzhen Walmart Workers' Collective Actions [in Chinese]. Chinese Workers, 21 June 2013. Available at http://www.chineseworkers.com.cn/_d276102331.htm [accessed 3 May 2014].

Howell, J. (1995) Prospects for NGOs in China. Development in Practice, 5(1), 5-15.

Howell, J. (2015) Shall We Dance? Welfarist Incorporation and the Politics of State-Labour NGO Relations. The China Quarterly, 223: 702-723.

Hui, E. and H. Timmons (2015) Workers at China's Largest Athletic Shoe Maker are Poised for Another Historic Strike. Quartz Media LLC UST. Available at https://qz.com/370675/workers-at-chinas-largestsneaker-maker-are-poised-for-another-historic-strike/ [accessed 29 June 2017].

Lai, C. (2016) Guangdong Labour Activist Meng Han Sentenced to One Year, Nine Months. Hong Kong Free Press, 3 November. Available at https://www.hongkongfp.com/2016/11/03/guangdong-labour-activistmeng-han-sentenced-1-year-9-months/ [accessed 5 August, 2017].

Lau, M. (2014) Yue Yuen Shoe Factory Workers' Strike at Dongguan Plants Continues. South China Morning Post, 16 April 2014.

Lee, C.K. (1998) Gender and the South China Miracle: Two Worlds of Factory Women. Berkeley: University of California Press.

Lee, C.K. and Y. Shen (2011) The Anti-Solidarity Machine? Labor Nongovernmental Organizations in China. From Iron Rice Bowl to Informalization: Markets, Workers, and the State in a Changing China, edited by S. Kuruvilla, C.K. Lee and M.E. Gallagher. Ithaca, NY: Cornell/ILR Press.

Leavenworth, S. (2016) China puts Human Rights Activists on Trial. The Guardian. Available at https://www.theguardian.com/world/2016/aug/02/china-puts-human-rights-activists-on-trial [accessed 20 January 2018].

Li, C. and M. Liu (2016) A Pathway to a Vital Labour Movement in China? A Case Study of a Union-Led Protest against Walmart. In China at Work: A Labour Process Perspective on the Transformation of Work and Employment in Cbina, edited by M. Liu and C. Smith. New York: Palgrave Macmillan.

Ministry of Public Security of the People's Republic of China (2016) Law of the People's Republic of China on Administration of Activities of Overseas Nongovernmental Organizations in Mainland China. Available at http://www.mps.gov.cn/n2254314/n2254409/n4904353/c5548987/content.html.17 November 2016 [accessed 7 August 2017].

Ong, L. (Forthcoming 2018) Thugs and Outsourcing of State Repression in China. The China Journal, no. 80.

Pun, N. (2005) Made in China: Women Factory Workers in a Global Workplace. Durham: Duke University Press. 
Phillips. T. (2015) Call for China to Free Labour Activists or Risk Backlash from Frustrated Workforce. The Guardian, 10 December 2015.

Phillips, T. and O. Holmes (2016) China Steps Up Human Rights Crackdown with Arrest of Foreign Activist. The Guardian, 13 January 2016.

Pringle, T. and G. Crothall (2017) China's Walmart Workers: Creating an Opportunity for Genuine Trade Unionism. China Labour Bulletin. Available at http://www.clb.org.hk/sites/default/files/Walmart\%20report\%20Final.pdf [accessed 14 October 2018].

Qiu, H. (2017) Why did the 2016 Chinese Walmart Workers' Movement Fail? Three Most Important Reasons [n Chinese]. Gongping, 14 February 2017. Available at http://mp.weixin.qq.com/s/1RbNQWeuoGdr5clUlM6ydg [accessed 28 June 2017].

Shi-Kipfer, K. and B. Lang (2017) Overseas NGOs in China: Left in Legal Limbo. The Diplomat. Available at http://thediplomat.com/2017/03/overseas-ngos-in-china-left-in-legal-limbo/ [accessed 30 June 2017].

Spires, A.J. (2011) Contingent Symbiosis and Civil Society in an Authoritarian State: Understanding the Survival of China's Grassroots NGOs. American Journal of Sociology, 117(1): 1-45.

Unger J., D. Beaumont and A. Chan (2011) Did Unionization Make a Difference? Work Conditions and Trade Union Activity at Chinese Walmart Stores. In Walmart in China, edited by A. Chan. Ithaca, NY: Cornell/ILR Press.

Walmart Chinese Workers Association (WCWA) (2014) Walmart Chinese Workers Association Announces its Establishment. Available at http://blog.sina.com.cn/wmunion 2014-09-08 21:22:24 [accessed 9 September 2017].

Walmart Chinese Workers Associaiton (WCWA) (2016) Exposing the True Face of Zhang Zhiru and Wang Jiangsong et. al. [in Chinese]. Available at http://blog.sina.com.cn/s/blog_165118a8b0102w8z9.html [accessed 17 January 2018].

Wen, Y. (2012) Hired Thugs Attack NGOs. Radio Free Asia, 8 September 2014. Available at <http://www.rfa.org/english/news/china/thugs-08312012151955.html> [accessed 9 August 2014].

Wikipedia. Han Dongfang. Available at https://en.wikipedia.org/wiki/Han_Dongfang [accessed 2 August 2017].

Xu, Y. (2013) Labor Nongovernmental Organizations in China: Mobilizing Rural Migrant Workers. Journal of Industrial Relations, 55: 243-259.

Zhang, C. (2015) Uncover the True Face of the 'Labour Movement Star' [in Chinese]. The People's Daily, 23 December 2015. Available at http://politics.people.com.cn/n1/2015/1223/c1001-27963407.html [accessed 24 December 2015].

\section{BIOGRAPHICAL NOTE}

ANITA CHAN is currently a Visiting Fellow at the Australian National University and one of the two editors of The China Journal. She was formerly a Research Professor at the University of Technology, Sydney. She has published more than 100 refereed articles and a dozen books, including, as editor, Walmart in China (2011) and Chinese Workers in Comparative Perspective (2015), both with Cornell/ILR Press. Her last project was on China's auto workers, and her current project is on comparing the industrial relations systems of China and Vietnam. [Email: anita.chan@anu.edu.au] 